\title{
Analgesic Effects of Fatty Acid Amide Hydrolase Inhibition in a Rat Model of Neuropathic Pain
}

\author{
Maulik D. Jhaveri, ${ }^{1}$ Denise Richardson, ${ }^{2}$ David A. Kendall, ${ }^{1}$ David A. Barrett, ${ }^{2}$ and Victoria Chapman ${ }^{1}$ \\ ${ }^{1}$ School of Biomedical Sciences, Medical School, Queens Medical Centre, University of Nottingham, Nottinghamshire NG7 2UH, United Kingdom, and \\ ${ }^{2}$ School of Pharmacy, University of Nottingham, Nottinghamshire NG7 2RD, United Kingdom
}

Cannabinoid-based medicines have therapeutic potential for the treatment of pain. Augmentation of levels of endocannabinoids with inhibitors of fatty acid amide hydrolase (FAAH) is analgesic in models of acute and inflammatory pain states. The aim of this study was to determine whether local inhibition of FAAH alters nociceptive responses of spinal neurons in the spinal nerve ligation model of neuropathic pain. Electrophysiological studies were performed 14-18 d after spinal nerve ligation or sham surgery, and the effects of the FAAH inhibitor cyclohexylcarbamic acid 3-carbamoyl biphenyl-3-yl ester (URB597) on mechanically evoked responses of spinal neurons and levels of endocannabinoids were determined.

Intraplantar URB597 $(25 \mu \mathrm{g}$ in $50 \mu \mathrm{l})$ significantly $(p<0.01)$ attenuated mechanically evoked responses of spinal neurons in sham-operated rats. Effects of URB597 were blocked by the cannabinoid 1 receptor $\left(\mathrm{CB}_{1}\right)$ antagonist AM251 [N-1-(2,4-dichlorophenyl)5-(4-iodophenyl)-4-methyl- $\mathrm{N}$-1-piperidinyl-1 $\mathrm{H}$-pyrazole-3-carboxamide] (30 $\mu \mathrm{g}$ in $50 \mu \mathrm{l}$ ) and the opioid receptor antagonist naloxone. URB597 treatment increased levels of anandamide, 2-arachidonyl glycerol, and oleoyl ethanolamide in the ipsilateral hindpaw of shamoperated rats. Intraplantar URB597 $(25 \mu \mathrm{g}$ in $50 \mu \mathrm{l})$ did not, however, alter mechanically evoked responses of spinal neurons in spinal nerve ligated (SNL) rats or hindpaw levels of endocannabinoids. Intraplantar injection of a higher dose of URB597 (100 $\mu \mathrm{g}$ in $50 \mu \mathrm{l})$ significantly $(p<0.05)$ attenuated evoked responses of spinal neurons in SNL rats but did not alter hindpaw levels of endocannabinoids. Spinal administration of URB597 attenuated evoked responses of spinal neurons and elevated levels of endocannabinoids in shamoperated and SNL rats. These data suggest that peripheral FAAH activity may be altered or that alternative pathways of metabolism have greater importance in SNL rats.

Key words: electrophysiology; endocannabinoid; spinal nerve ligation; $\mathrm{URB} 597 ; \mathrm{CB}_{1}$ receptor; opioid receptor

\section{Introduction}

Recent studies suggest that cannabis-based medicines have therapeutic potential for the treatment of neuropathic pain states (Hohmann, 2002). Activation of both the cannabinoid 1 receptor $\left(\mathrm{CB}_{1}\right)$ and $\mathrm{CB}_{2}$ reduces nociceptive processing in animal models of neuropathic pain (Hohmann, 2002; Howlett et al., 2002; Elmes et al., 2004; Sagar et al., 2005). Furthermore, nociceptive processing is tonically modulated by the endocannabinoids. Both $\mathrm{CB}_{1}$ receptor antisense oligonucleotides (Richardson et al., 1998; Dogrul et al., 2002) and $\mathrm{CB}_{1}$ receptor antagonists facilitate nociceptive responses (Herzberg et al., 1997; Richardson et al., 1997, 1998; Calignano et al., 1998; Strangman et al., 1998; Chapman, 1999).

A novel experimental approach to treating pain is the augmentation of levels of endocannabinoids. Fatty acid amide hy-

Received March 24, 2006; revised 0ct. 31, 2006; accepted Nov. 16, 2006.

This work was supported by the Wellcome Trust. D.R. was supported by a Biotechnology and Biological Sciences Research Council Studentship. We thank Fernando Pérez-Diaz (Hôpital de La Salpêtrière, Paris, France) for advice on the statistics.

Correspondence should be addressed to Dr. Maulik D. Jhaveri, School of Biomedical Sciences, Medical School, Queen's Medical Centre, University of Nottingham, Nottinghamshire NG7 2UH, UK. E-mail: maulik.jhaveri@nottingham.ac.uk.

DOI:10.1523/JNEUROSCI.3326-06.2006

Copyright $\odot 2006$ Society for Neuroscience $\quad$ 0270-6474/06/2613318-10\$15.00/0 drolase (FAAH) is the main enzyme responsible for the metabolism of several endogenous fatty acid amides, including anandamide (AEA), palmitoylethanolamide, and oleamide (Deutsch and Chin, 1993; Desarnaud et al., 1995; Maurelli et al., 1995; Ueda et al., 1995; Cravatt et al., 1996). FAAH inhibitors, such as cyclohexylcarbamic acid 3-carbamoyl biphenyl-3-yl ester (URB597) and 1-oxo-1[5-(2-pyridyl)-2-yl]-7-phenyl heptane (OL135), or deletion of the FAAH gene increases levels of anandamide in vivo and in vitro (Cravatt et al., 2001; Clement et al., 2003; Kathuria et al., 2003; Lichtman et al., 2004b; Fegley et al., 2005; Hohmann et al., 2005; Makara et al., 2005). FAAH-null mice are hypoalgesic in models of acute and inflammatory pain, effects that are blocked by a $\mathrm{CB}_{1}$ receptor antagonist (Cravatt et al., 2001; Lichtman et al., 2004a). In contrast to studies of acute and inflammatory pain, it is less clear whether elevating levels of endocannabinoids modulates aberrant pain responses in models of neuropathic pain. Indeed, thermal hyperalgesia has been shown to develop in a similar manner in wild-type and FAAHnull mice in the chronic constriction injury model of neuropathic pain (Lichtman et al., 2004a). Furthermore, in the partial nerve ligation model of neuropathic pain, systemic administration of URB597 did not alter neuropathic pain behavior (Jayamanne et al., 2006).

The first aim of this study was to determine whether local 
peripheral or spinal inhibition of FAAH modulates nociceptive responses in neuropathic rats compared with sham-operated rats and to determine the contribution of the $\mathrm{CB}_{1}$ receptors to these effects. Endogenous opioids and peripheral opioid receptors have been implicated in cannabinoid receptor-mediated antinociception in models of acute pain (Ibrahim et al., 2005). The contribution of $\mu$-opioid receptor mechanisms to the analgesic effects of endocannabinoids is unknown, and therefore, the ability of the $\mu$-opioid receptor antagonist naloxone to attenuate the effects of URB597 has also been investigated. The second part of this study investigated the mechanism of action of URB597 on nociceptive responses by determining whether URB597 alters levels of endocannabinoids and related fatty acids in the hindpaw and spinal cord tissue of neuropathic and sham-operated rats.

\section{Materials and Methods}

All experiments were performed in accordance with the United Kingdom Home Office Animals (Scientific Procedures) Act of 1986. Experiments were performed on 143 Sprague Dawley rats (240-300 g), which were group housed in a light-controlled room with ad libitum access to food and water. Rats were divided into 26 experimental groups, of which 11 were sham operated, and 15 were spinal nerve ligated (SNL). Electrophysiological experiments were performed in 17 groups, of which 7 were sham operated, and 10 were SNL. One neuron was recorded per rat. The remaining nine groups were used for endocannabinoid measurement.

Spinal nerve ligation. The spinal nerve ligation model of neuropathic pain was used in this study. Spinal nerves L5-L6 were ligated according to the procedures described by Kim and Chung (1992). Male Sprague Dawley rats $(110-130 \mathrm{~g})$ were anesthetized using isoflurane (induction, $3 \%$; maintenance, $1-1.5 \%$; in $33 \% \mathrm{O}_{2} / 67 \% \mathrm{~N}_{2} \mathrm{O}$ ) and placed in a prone position. A midline incision was made at the L3-S2 level, and the left paraspinal muscles at $\mathrm{L} 4-\mathrm{S} 2$ level were separated from spinal processes. Part of the L6 transverse process was removed with fine rongeurs, and the L4-L6 nerves were identified. The L5-L6 spinal nerves were isolated and tightly ligated distal to the dorsal root ganglia and proximal to the sciatic nerve formation with 6-0 silk. The wound was closed in two layers using absorbable sutures and wound clips, after complete hemostasis. A similar procedure was performed for the sham surgery, except spinal nerves were not ligated. After surgery, the sham-operated and SNL rats were group housed, and their posture and behavior were closely monitored for $48 \mathrm{~h}$. From postoperative day 2 onwards, behavioral testing was performed to assess the development of mechanical allodynia up to day 11 after surgery. Rats were placed in Perspex cubicles with wire mesh grid floors and allowed to acclimatize before behavioral testing. Mechanical sensitivity of the ipsilateral and contralateral hindpaws was assessed by measuring the percentage of foot withdrawal in response to normally innocuous mechanical punctuate stimuli. Stimuli were delivered, from below, to the plantar surface of the foot using a $10 \mathrm{~g}$ von Frey hair stimulus. Each trial consisted of the application of a single von Frey hair 10 times. Trials were separated by $5 \mathrm{~min}$. At 14-18 d after surgery, in vivo electrophysiological studies were performed, or tissue was collected for measurement of levels of endocannabinoids in hindpaw and spinal cord.

Electrophysiology. Methods were similar to those described previously (Sokal and Chapman, 2001). Rats were anesthetized with isoflurane inhalation anesthetic (induction, $3 \%$; surgery, $2 \%$; maintenance, $1-1.5 \%$; in $33 \% \mathrm{O}_{2} / 67 \% \mathrm{~N}_{2} \mathrm{O}$ ), and a tracheal cannula was inserted. Rats were then placed in a stereotaxic frame to maintain stability during recordings. A laminectomy was performed, lumbar vertebrae L1-L3 were located, and segments L4-L5 of the spinal cord were exposed using fine rongeurs. The spinal cord was held rigid by clamps rostral and caudal to the exposed section of spinal cord (L4/5), and a small well was formed with the surrounding muscle. Core body temperature was maintained at 36.5$37.5^{\circ} \mathrm{C}$ throughout the experiment by means of a heating blanket connected to a rectal temperature probe.

Extracellular single-unit recordings of deep (500-1000 $\mu \mathrm{m})$ wide dynamic range (WDR) dorsal horn neurons were made with glass-coated tungsten microelectrodes. Electrodes were lowered vertically through the cord with a SCAT-01 microdrive (Digitimer, Welwyn Garden City, UK), and depths of recorded neurons from the spinal cord surface were noted. Receptive fields of neurons covering one or two toes were identified using brush, pinch, and heat stimuli. Single-unit activity was amplified and filtered (Digitimer). Signals were digitized and analyzed using a Cambridge Electronic Design micro 1401 interface and Spike 2 data acquisition software (Cambridge Electronic Design, Cambridge, UK). Responses of neurons to a train of 16 transcutaneous electrical stimuli ( 0.5 $\mathrm{Hz} ; 2$ ms pulse width) applied to the center of the receptive field were recorded. All neurons selected were WDR, exhibiting a short-latency A $\beta$-fiber-evoked response ( $0-20 \mathrm{~ms}$ after stimulus) and A $\delta$-fiber-evoked response (20-90 ms after stimulus). These neurons also exhibited longer-latency C-fiber-evoked responses (90-300 ms after stimulus) and postdischarge responses ( $300-800 \mathrm{~ms}$ after stimulus).

Responses of neurons to punctate mechanical stimulation of the peripheral receptive field of varying bending force $(8,10,15,26$, and $60 \mathrm{~g})$ were characterized. This range of von Frey hairs includes non-noxious and noxious stimuli, because the noxious stimulation-induced paw withdrawal threshold in awake animals is $15 \mathrm{~g}$ (Chaplan et al., 1994). Individual von Frey hairs were applied to the center of the receptive field for $10 \mathrm{~s}$ in ascending order. Mechanical stimulation of the receptive field was repeated every $10 \mathrm{~min}$. Once stable control responses ( $<10 \%$ variation) were obtained, pharmacological studies were performed.

Drug treatment. In sham-operated rats, effects of intraplantar injections of URB597 (25 $\mu \mathrm{g}$ in $50 \mu \mathrm{l} ; n=6$; Alexis Biochemicals, Lausen, Switzerland) or vehicle (50 $\mu$ l of $3 \%$ Tween 80 in physiological saline; $n=4)$ on mechanically evoked responses of WDR neurons were recorded for $60 \mathrm{~min}$. Similarly, effects of intraplantar injection of URB597 (25 and $100 \mu \mathrm{g}$ in $50 \mu \mathrm{l} ; n=6$ ) or vehicle $(n=4)$ were studied in SNL rats. The contributions of $\mathrm{CB}_{1}$ versus $\mu$-opioid receptors to the inhibitory effects of URB597 were investigated. In a separate groups of rats, the effects of intraplantar injection of the $\mathrm{CB}_{1}$ antagonist $\mathrm{N}$-1-(2,4-dichlorophenyl)-5-(4-iodophenyl)-4-methyl- $N$-1-piperidinyl- $1 \mathrm{H}$-pyrazole-3-carboxamide (AM251; $30 \mu \mathrm{g}$ in $50 \mu \mathrm{l} ; n=6$; Tocris Bioscience, Bristol, UK) or the opioid antagonist naloxone (10 $\mu \mathrm{g}$ in $50 \mu \mathrm{l}$ of physiological saline; $n=6$; Sigma, Poole, UK), $30 \mathrm{~min}$ before intraplantar injection of URB597, on URB597-mediated inhibitions were investigated in shamoperated and SNL rats for an additional $60 \mathrm{~min}$. To ascertain whether the effects of URB597 were attributable to a local site of action, the effects of a contralateral injection of URB597 (100 $\mu \mathrm{g}$ in $50 \mu \mathrm{l})$ on ipsilateral hindpaw stimulation-evoked neuronal responses were studied in a separate group of SNL rats $(n=6)$.

In separate groups of sham-operated $(n=6)$ and SNL $(n=8)$ rats, effects of spinal application of URB597 $(10,25$, and $50 \mu \mathrm{g}$ in $50 \mu \mathrm{l})$ directly onto the exposed spinal cord on mechanically evoked responses of WDR neurons were recorded for $50 \mathrm{~min}$ per dose. The ability of spinal administration of the $\mathrm{CB}_{1}$ receptor antagonist AM251 ( $1 \mu \mathrm{g}$ in $\left.50 \mu \mathrm{l}\right) 30$ min before URB597 ( $50 \mu \mathrm{g}$ in $50 \mu \mathrm{l}$ ) or naloxone $10 \mathrm{~min}$ before URB597 $(50 \mu \mathrm{g}$ in $50 \mu \mathrm{l})$ to attenuate the inhibitory effect of URB597 on mechanically evoked responses of WDR neurons was also studied in shamoperated $(n=5-6)$ and SNL rats $(n=5-6)$. The doses of AM251 (Johanek and Simone, 2004; Ibrahim et al., 2005) and naloxone (Dickenson and Sullivan, 1986; Johanek and Simone, 2004; Ibrahim et al., 2005) used were based on previously published literature.

Measurement of endocannabinoids in hindpaw skin and spinal cord. Separate groups of SNL and sham-operated rats were anesthetized as described above. URB597 ( 25 and $100 \mu \mathrm{g}$ in $50 \mu \mathrm{l} ; n=6$ ) or vehicle ( $3 \%$ Tween 80 in saline; $n=6$ ) was injected into the ipsilateral hindpaw of rats in a manner identical to that performed for the electrophysiological experiments. Twenty minutes later, the rats were killed, and the ipsilateral and contralateral hindpaw skin was dissected and stored at $-80^{\circ} \mathrm{C}$ for measurement of endocannabinoids and related compounds. In separate groups of SNL and sham-operated rats, URB597 (50 $\mu \mathrm{g}$ in $50 \mu \mathrm{l} ; n=6$ ) or vehicle ( $3 \%$ Tween 80 in saline; $n=4)$ was applied directly to the spinal cord. Thirty minutes later, the rats were killed, the ipsilateral and contralateral spinal cord was dissected, and the tissue was stored at $-80^{\circ} \mathrm{C}$ for 2 to 4 weeks before spectrometric analysis.

A lipid extraction method was used; in brief, tissue was homogenized in an ethyl acetate/hexane mixture with internal standards added in fixed 
amounts to all samples [0.42 $\mathrm{nmol}$ of anandamide-d8, $1.5 \mathrm{nmol}$ of 2 -arachidonyl glycerol (2AG)-d8, and $0.2 \mathrm{nmol}$ of heptadecanoyl ethanolamide (HEA)], followed by repeated centrifugation and supernatant collection stages. Anandamide- $\mathrm{d} 8$ was used as an internal standard for AEA, palmitoyl ethanolamide (PEA), oleoyl ethanolamide (OEA), and virodhamine; 2 -arachidonyl glycerol-d8 was used as an internal standard for 2AG, 2-linoleoylglycerol (2LG), and noladin ether; and HEA was used as internal standard for arachidonyl glycine.

Solid-phase extraction was subsequently performed to purify samples. Simultaneous measurement of endocannabinoids and related compounds was then performed using liquid chromatography-tandem mass spectrometry. Analysis was performed on an Agilent (Agilent Technologies, Waldbronn, Germany) 1100 system coupled to a triple quadrupole Quattro Ultima MS (Waters, Manchester, UK) recording in electrospray-positive mode. Analytes were separated chromatographically on a HyPurity Advance C8 column and precolumn (internal diameter, $100 \times 2.1 \mathrm{~mm}$; particle size, $3 \mu \mathrm{m}$; Thermo Fisher Scientific, Rocurn, UK) with a mobile-phase flow rate of $0.3 \mathrm{ml} / \mathrm{min}$. A gradient elution was used, with mobile phases consisting of A (water, $1 \mathrm{~g} / \mathrm{L}$ ammonium acetate, and $0.1 \%$ formic acid) and B (acetonitrile, $1 \mathrm{~g} / \mathrm{L}$ ammonium acetate, and $0.1 \%$ formic acid). Samples were injected from a cooled auto sampler maintained at $4^{\circ} \mathrm{C}$. Multiple-reaction monitoring of individual compounds using specific precursor and product mass-to-charge $(\mathrm{m} / \mathrm{z}) \mathrm{ra}$ tios allowed simultaneous measurement of AEA, 2AG, PEA, OEA, 2LG, virodhamine, noladin ether, and arachidonyl glycine. The peak area of each analyte was divided by the appropriate internal standard peak area, and this analyte/internal standard ratio was used to achieve quantitation by the internal standard method. Individual calibration lines were obtained during each analytical run by applying the method to a suitable range of concentrations of the nondeuterated forms of each analyte. Data is reported only for analytes above the limit of quantitation by this method [ $10 \mathrm{pmol} / \mathrm{g}$ except for $2 \mathrm{AG}$ $(100 \mathrm{pmol} / \mathrm{g})]$. The method used here has been validated for the measurement of endocannabinoids and was described in detail previously (Richardson et al., 2006).

Data analysis. Control mechanically evoked responses of WDR neurons were the average of three trains of stimulation before vehicle/drug injection. Properties (control evoked responses and depth) of WDR neurons before drug/vehicle administration were statistically compared using $t$ test or one-way ANOVA as appropriate. Comparisons of the effects of vehicle versus URB597 on evoked activity of WDR neurons after injection into the receptive field were performed with one-way ANOVA. The time course of effects of drug treatments on evoked responses of WDR neurons of SNL and sham-operated rats were analyzed using repeated-measures ANOVA followed by Dunnett's post hoc test to identify the time point of maximal drug effect (data not shown). For comparison of the maximal effects of vehicle versus drug treatment on neuronal responses in SNL or sham-operated rats, data were normalized and expressed as a percentage of the predrug control value. This was performed to take into account any inherent variation in control evoked responses before drug treatment between individual rats. Given the size of groups compared, these data were analyzed with a nonparametric MannWhitney test, and $p<0.05$ was considered significant. Data are expressed as mean \pm SEM of percentage of control responses. Endocannabinoid levels were calculated as the ratio of the area of the endocannabinoid peak to its internal standard on the spectrogram and are expressed as moles per gram of wet weight of tissue. Spectrometric data were statistically compared using a Mann-Whitney nonparametric test and are presented as mean \pm SEM.

\section{Results}

\section{Development of mechanical allodynia in SNL rats}

After spinal nerve ligation surgery, rats exhibited normal grooming behavior and weight gain similar to the sham-operated controls. The development of mechanical allodynia was assessed for up to $17 \mathrm{~d}$ after surgery. Before electrophysiological studies, rats exhibited significant mechanical allodynia. On day 11 after surgery, application of a $10 \mathrm{~g}$ mechanical stimulus to the ipsilateral hindpaw of SNL rats evoked a significant increase in paw with- drawal $(58 \pm 8 \%$ paw withdrawal; $p<0.001$; mean \pm SEM; $n=$ 28 ) compared with sham-operated rats ( $1 \pm 1 \%$ paw withdrawal; $n=22$ ). Similarly, at day 17 after surgery, application of a $10 \mathrm{~g}$ stimulus to the ipsilateral hindpaw of SNL rats produced hindpaw withdrawal ( $78 \pm 8 \%$ paw withdrawal; $n=7)$. In contrast, a $10 \mathrm{~g}$ stimulation of the contralateral hindpaw did not evoke a significant paw withdrawal in SNL or sham-operated rats (data not shown). Thus SNL rats developed marked mechanical allodynia after tight ligation of L5 and L6 nerves, which is in agreement with previous studies of this model (Kim and Chung, 1992; Chapman et al., 1998; Elmes et al., 2004; Jhaveri et al., 2005).

\section{Characteristics of neuronal responses of SNL and sham-operated rats}

In vivo single-unit extracellular recordings of dorsal horn neurons were performed between postoperative days 14 and 18 in SNL and sham-operated anesthetized rats. The mean depths of WDR neurons (500-1000 $\mu \mathrm{m}$; corresponding to lamina V-VI) and control electrically evoked A- and C-fiber responses were similar for the population of neurons recorded from shamoperated and SNL rats (Table 1). Predrug control mechanically evoked responses of WDR neurons increased incrementally after the application of ascending weights of calibrated von Frey monofilaments $(8-60 \mathrm{~g})$ to the center of the receptive field on the hindpaw. The frequencies of mechanically evoked responses of WDR neurons in SNL rats were significantly lower than in shamoperated rats (Fig. 1), which is in keeping with a previous report (Chapman et al., 1998).

\section{Effects of intraplantar injection of URB597 on responses of WDR neurons in SNL and sham-operated rats}

Insertion of the needle and injection of URB597 or vehicle into the peripheral receptive field induced firing of WDR neurons, which often persisted after removal of the needle. The frequency and duration of firing of WDR neurons immediately after intraplantar injection of URB597 (25 $\mu \mathrm{g}$ in $50 \mu \mathrm{l}$ per rat) into the peripheral receptive field was not significantly $(p>0.05)$ different from the effects of vehicle in both sham-operated and SNL rats (data not shown).

Intraplantar injection of vehicle produced minor increases in mechanically evoked responses of WDR neurons, compared with predrug control responses, in both sham-operated and SNL rats. Although these increases in response were not significant, they may reflect a small peripheral sensitization after intraplantar injection of vehicle. There were no significant differences between the effects of intraplantar injection of vehicle on mechanically evoked responses of WDR neurons in sham-operated and SNL rats, and therefore these data were pooled for statistical comparisons and clarity of presentation. Intraplantar injection of URB597 $(25 \mu \mathrm{g}$ in $50 \mu \mathrm{l})$ significantly reduced mechanically evoked responses of WDR neurons in sham-operated rats, with the exception of the 60-g-evoked response, compared with vehicle (Fig. 2). Maximal inhibitory effects of URB597 were observed at $20 \mathrm{~min}$ after injection. In contrast, intraplantar injection of URB597 (25 $\mu \mathrm{g}$ in $50 \mu \mathrm{l}$ ) had no significant effect on mechanically evoked responses of WDR neurons in SNL rats (Fig. 2). However, intraplantar injection of a higher dose of URB597 (100 $\mu \mathrm{g}$ in $50 \mu \mathrm{l}$ ) significantly inhibited the mechanically evoked responses of WDR neurons in SNL rats. Effects of the higher dose of URB597 in SNL rats were comparable with the effects of URB597 $(25 \mu \mathrm{g}$ in $50 \mu \mathrm{l})$ in sham-operated rats. Intraplantar injection of URB597 (100 $\mu \mathrm{g}$ in $50 \mu \mathrm{l})$ in the contralateral paw did not alter mechanically evoked responses of dorsal horn neurons in SNL 


\begin{tabular}{|c|c|c|c|c|c|c|}
\hline & \multirow[b]{2}{*}{$n$} & \multirow[b]{2}{*}{ Depth $(\mu \mathrm{m})$} & \multicolumn{4}{|c|}{ Evoked responses $(\mathrm{Hz})$} \\
\hline & & & $A \beta$ & $A \delta$ & $C$ & PD \\
\hline \multicolumn{7}{|l|}{ Sham rats } \\
\hline \multicolumn{7}{|l|}{ Intraplantar } \\
\hline Vehicle & 4 & $815 \pm 51$ & $203 \pm 19$ & $268 \pm 56$ & $622 \pm 100$ & $635 \pm 188$ \\
\hline URB $(25 \mu \mathrm{g})$ & 6 & $912 \pm 28$ & $178 \pm 24$ & $179 \pm 38$ & $418 \pm 74$ & $349 \pm 99$ \\
\hline AM251 plus URB $(25 \mu \mathrm{g})$ & 6 & $698 \pm 64$ & $143 \pm 18$ & $162 \pm 34$ & $514 \pm 71$ & $637 \pm 106$ \\
\hline Nal plus URB $(25 \mu \mathrm{g})$ & 6 & $692 \pm 61$ & $156 \pm 16$ & $177 \pm 18$ & $431 \pm 58$ & $428 \pm 83$ \\
\hline \multicolumn{7}{|l|}{ Spinal } \\
\hline URB $(10,25$, and $50 \mu \mathrm{g})$ & 6 & $820 \pm 40$ & $163 \pm 29$ & $176 \pm 29$ & $585 \pm 140$ & $363 \pm 120$ \\
\hline AM251 plus URB (50 $\mu \mathrm{g})$ & 6 & $744 \pm 70$ & $113 \pm 10$ & $145 \pm 40$ & $522 \pm 82$ & $492 \pm 130$ \\
\hline Nal plus URB (50 $\mu \mathrm{g})$ & 5 & $730 \pm 56$ & $136 \pm 9$ & $149 \pm 10$ & $547 \pm 46$ & $519 \pm 152$ \\
\hline \multicolumn{7}{|l|}{ SNL rats } \\
\hline \multicolumn{7}{|l|}{ Intraplantar } \\
\hline Vehicle & 4 & $760 \pm 138$ & $167 \pm 14$ & $167 \pm 8$ & $365 \pm 68$ & $245 \pm 50$ \\
\hline URB $(25 \mu \mathrm{g})$ & 6 & $723 \pm 87$ & $142 \pm 21$ & $151 \pm 20$ & $372 \pm 57$ & $333 \pm 72$ \\
\hline URB $(100 \mu \mathrm{g})$ & 6 & $755 \pm 54$ & $150 \pm 12$ & $219 \pm 29$ & $580 \pm 73$ & $722 \pm 112$ \\
\hline AM251 plus URB (100 $\mu \mathrm{g})$ & 6 & $712 \pm 54$ & $159 \pm 9$ & $184 \pm 25$ & $439 \pm 68$ & $434 \pm 124$ \\
\hline Nal plus URB $(100 \mu \mathrm{g})$ & 6 & $718 \pm 64$ & $153 \pm 12$ & $148 \pm 13$ & $327 \pm 27$ & $307 \pm 75$ \\
\hline URB $(100 \mu \mathrm{g})$ contralateral paw & 6 & $682 \pm 48$ & $147 \pm 7$ & $105 \pm 16$ & $274 \pm 35$ & $292 \pm 36$ \\
\hline \multicolumn{7}{|l|}{ Spinal } \\
\hline Vehicle & 5 & $610 \pm 46$ & $152 \pm 11$ & $177 \pm 34$ & $439 \pm 119$ & $385 \pm 135$ \\
\hline $\operatorname{URB}(10,25,50 \mu \mathrm{g})$ & 8 & $666 \pm 38$ & $88 \pm 8.4$ & $132 \pm 24$ & $484 \pm 77$ & $554 \pm 99$ \\
\hline AM251 plus URB $(50 \mu \mathrm{g})$ & 5 & $854 \pm 168$ & $102 \pm 14$ & $147 \pm 20$ & $598 \pm 99$ & $647 \pm 49$ \\
\hline Nal plus URB $(50 \mu \mathrm{g})$ & 6 & $852 \pm 73$ & $102 \pm 20$ & $160 \pm 13$ & $417 \pm 30$ & $509 \pm 84$ \\
\hline
\end{tabular}

Depths from the surface of the spinal cord and electrically ( $A \beta, A \beta$-fiber; $A \delta, A \delta$-fiber; $C, C$-fiber; $P D$, postdischarge) evoked responses of neurons were statistically compared using one-way $A N O V A$ with their respective controls. Data are expressed as mean \pm SEM. $n$, Number of neurons per group; URB, URB597; Nal, naloxone.

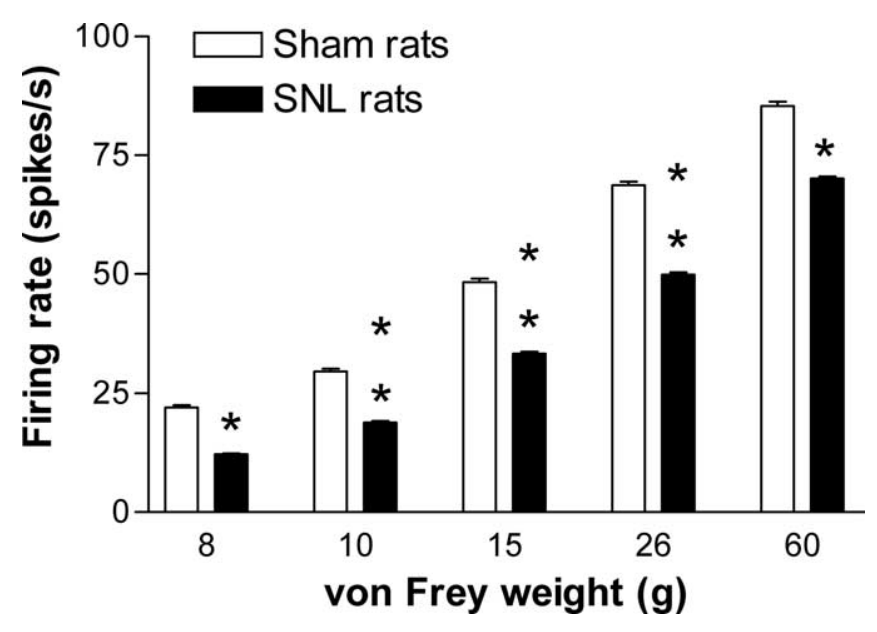

Figure 1. Control mechanically evoked responses of dorsal horn wide dynamic range neurons in sham-operated and SNL rats. Data were analyzed using a Mann-Whitney nonparametric test. ${ }^{*} p<0.05$ and ${ }^{* *} p<0.01$ versus sham. Data are expressed as mean + SEM $(n=$ $39-58$ neurons per group).

rats $(p>0.05$; Mann-Whitney test; $n=6$ ) compared with the effects of injection of vehicle in ipsilateral paw (mean \pm SEM; percentage of control evoked responses after contralateral URB597: $8 \mathrm{~g}, 108 \pm 16 ; 10 \mathrm{~g}, 116 \pm 22 ; 15 \mathrm{~g}, 102 \pm 13 ; 26 \mathrm{~g}, 114 \pm$ $16 ; 60 \mathrm{~g}, 99 \pm 6$ vs ipsilateral vehicle: $8 \mathrm{~g}, 155 \pm 38 ; 10 \mathrm{~g}, 131 \pm 12$; $15 \mathrm{~g}, 109 \pm 5 ; 26 \mathrm{~g}, 97 \pm 4 ; 60 \mathrm{~g}, 109 \pm 12$ ).

\section{Inhibitory effects of URB597 are attenuated by $\mathrm{CB}_{1}$ receptor blockade}

Intraplantar injection of the $\mathrm{CB}_{1}$ receptor antagonist AM251 (30 $\mu \mathrm{g}$ in $50 \mu \mathrm{l}$ ) did not alter mechanically evoked responses of spinal neurons during the $30 \mathrm{~min}$ pretreatment period in shamoperated and SNL rats, except for 8-g-evoked responses in the former group. AM251 significantly attenuated the inhibitory effects of URB597 (25 $\mu \mathrm{g}$ in $50 \mu \mathrm{l}$ ) on mechanically evoked re- sponses of WDR neurons in sham-operated rats (Fig. 2). Similarly, AM251 also attenuated the inhibitory effects of the higher dose of URB597 in SNL rats (Fig. 2). These data support the role of $\mathrm{CB}_{1}$ receptors in mediating the inhibitory effects of URB597 in both sham-operated and SNL rats.

Differential contributions of $\boldsymbol{\mu}$-opioid receptors to the inhibitory effects of URB597 in sham-operated and SNL rats Previous studies suggest that the inhibitory effects of peripherally administered cannabinoid agonists may be mediated, at least in part, by $\mu$-opioid receptors (Ibrahim et al., 2005). To investigate whether this interplay with the opioid receptor system extends to the endocannabinoids, the ability of the $\mu$-opioid receptor antagonist naloxone to attenuate the inhibitory effects of URB597 was also studied. Intraplantar injection of naloxone $(10 \mu \mathrm{g}$ in $50 \mu \mathrm{l})$ did not alter mechanically evoked responses of WDR neurons, compared with vehicle, during the 30 min pretreatment period in either sham-operated and SNL rats (Fig. 2). Pretreatment with naloxone did, however, attenuate the effects of URB597 on mechanically evoked responses of WDR neurons in sham-operated rats but not in SNL rats (Fig. 2).

\section{Effects of spinal administration of URB597 on responses of} WDR neurons in sham-operated and SNL rats

Spinal administration of vehicle ( $50 \mu \mathrm{l}$ of $3 \%$ Tween 80 in saline) at $50 \mathrm{~min}$ intervals over a $150 \mathrm{~min}$ period did not alter 8 - to 60-g-evoked WDR neuronal responses compared with prevehicle controls in SNL rats $(p>0.05$; repeated-measures ANOVA; $n=$ 5). All statistical comparisons were made with values from vehicle control data in SNL rats. Spinal administration of URB597 did not have significant effects on 8- and 10-g-evoked responses of WDR neurons in sham-operated and SNL rats, compared with vehicle controls (data not shown). URB597 (10, 25, and $50 \mu \mathrm{g}$ in $50 \mu \mathrm{l}$ ) dose-relatedly inhibited 15-g-evoked responses of WDR neurons in both sham-operated [percentage control \pm SEM, $\operatorname{URB} 597(10,25$, and $50 \mu \mathrm{g}), 123 \pm 33,67 \pm 32$, and $36 \pm 10$, 


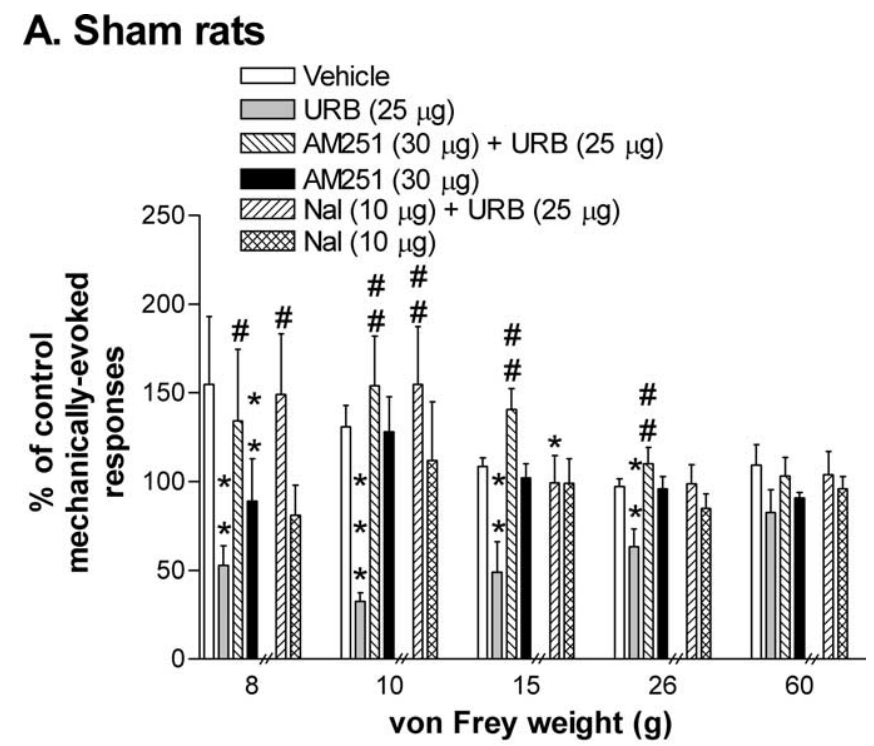

\section{B. SNL rats}

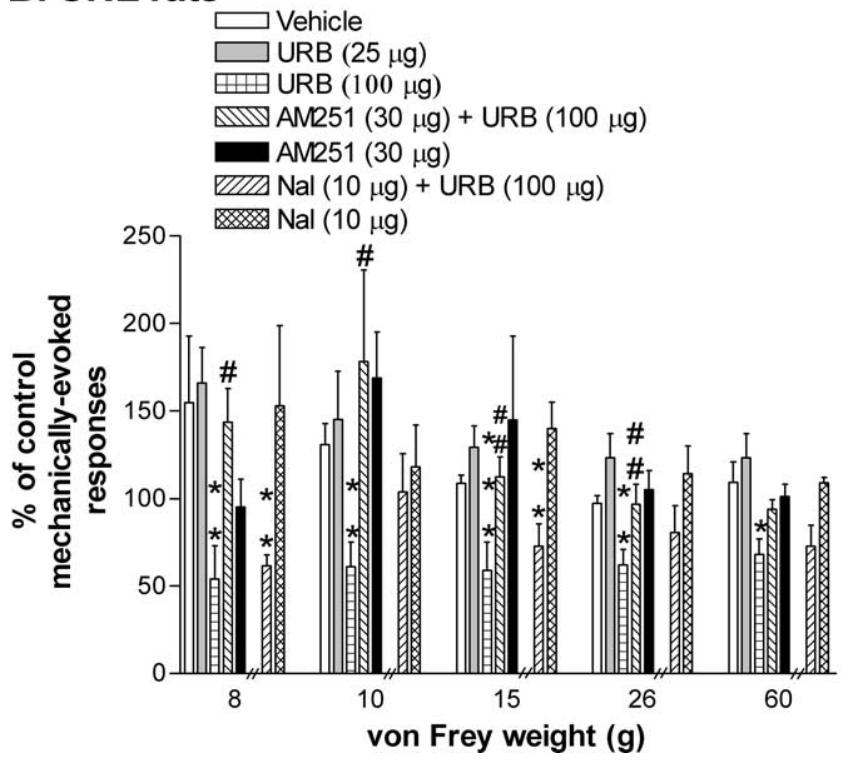

Figure 2. $\quad A, B$, Intraplantar injection of a low dose of URB597 (URB) reduced mechanically evoked responses of wide dynamic range neurons in sham-operated $(\boldsymbol{A})$ but not SNL $(\boldsymbol{B})$ rats. A higher dose of URB attenuated evoked responses in SNL rats. Inhibitory effects of URB were attenuated by AM251 $(30 \mu \mathrm{g})$ in both sham-operated and SNL rats. Inhibitory effects of URB were also attenuated by naloxone (Nal; $10 \mu \mathrm{g})$ in sham-operated rats. All drugs were given in a volume of $50 \mu \mathrm{l}$. Data were statistically analyzed with a nonparametric Mann-Whitney test. Effects of vehicle in sham-operated and SNL rats did not differ significantly and were pooled $(n=8) .{ }^{*} p<0.05,{ }^{* *} p<0.01$, and ${ }^{* * *} p<0.001$ versus vehicle. ${ }^{\#} p<0.05$ and ${ }^{\# \#} p<0.01$ versus URB (25 $\mu \mathrm{g})$-sham. ${ }^{\#} p<0.05$ and ${ }^{\#} p<0.01$ versus URB (100 $\left.\mu \mathrm{g}\right)-$ SNL. Data are expressed as mean + SEM ( $n=6-8$ neurons per group).

respectively] and SNL rats [percentage control \pm SEM, URB597 $(10,25$, and $50 \mu \mathrm{g}), 77 \pm 46,87 \pm 62$, and $55 \pm 40$, respectively]. Effects of spinal URB597 on 26- and 60-g-evoked responses of WDR neurons are presented in Figure 3. The lowest dose of URB597 studied (10 $\mu \mathrm{g}$ in $50 \mu \mathrm{l})$ significantly $(p<0.05)$ inhibited 15- and 60-g-evoked responses of WDR neurons in SNL rats, compared with time-matched vehicle controls, but not in shamoperated rats. URB597 (25 $\mu \mathrm{g}$ in $50 \mu \mathrm{l})$ significantly $(p<0.05)$ inhibited 26- and 60-g-evoked responses of WDR neurons in SNL rats, compared with time-matched vehicle controls. URB597 $(25 \mu \mathrm{g}$ in $50 \mu \mathrm{l})$ only significantly $(p<0.05)$ inhibited
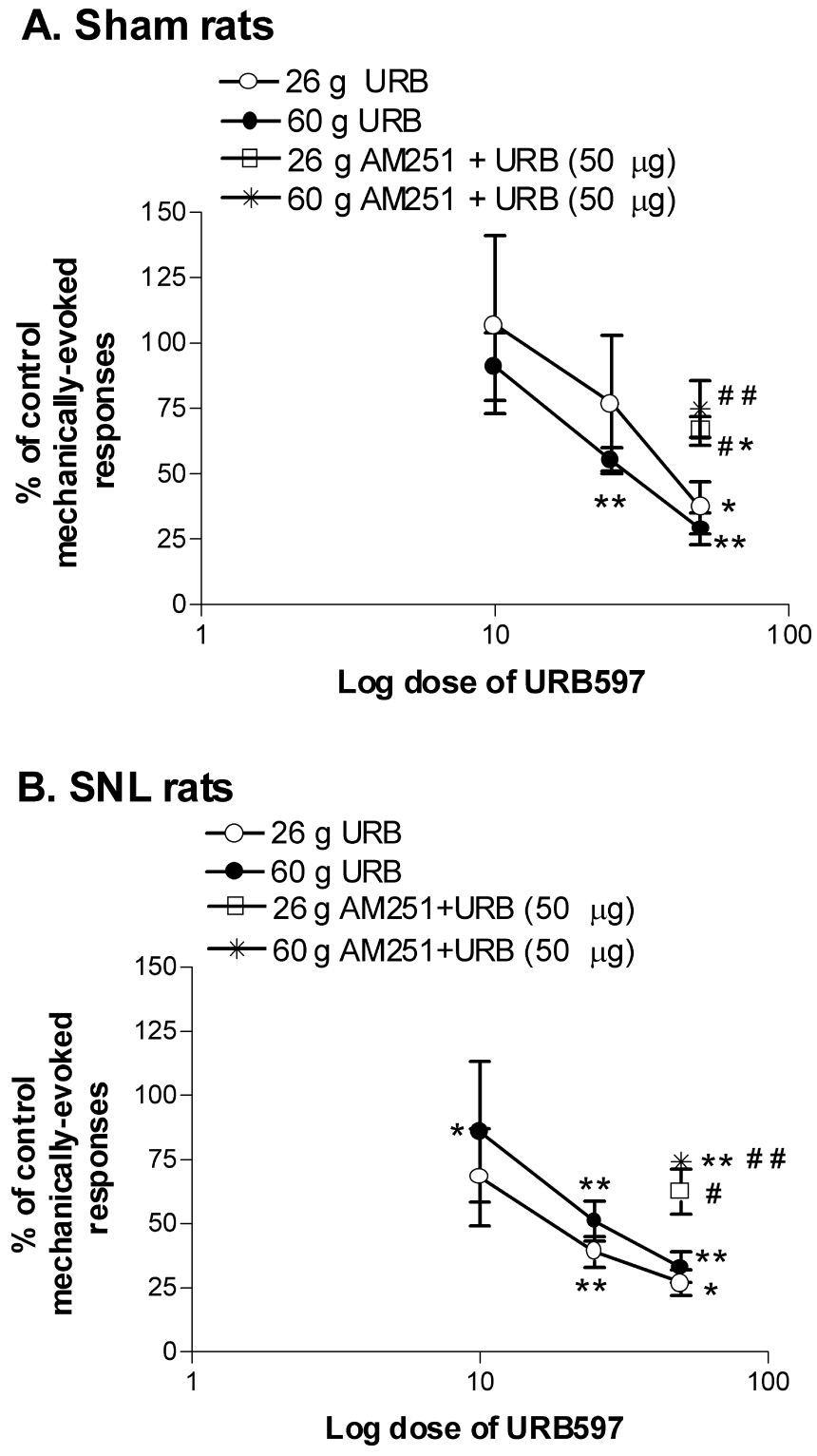

Figure 3. $\quad A, B$, Spinal administration of URB597 (URB; 10,25 , and $50 \mu \mathrm{g}$ ) dose-relatedly reduced 26- and 60-g-evoked responses of WDR neurons in sham-operated $(\boldsymbol{A})$ and SNL $(\boldsymbol{B})$ rats. Effects of URB597 were blocked by spinal preadministration of AM251 $(1 \mu \mathrm{g})$. All drugs were given in a volume of $50 \mu \mathrm{l}$. Data were statistically compared using a Mann-Whitney nonparametric test and are expressed as mean \pm SEM ( $n=5-8$ neurons per group). ${ }^{*} p<0.05$ and ${ }^{* *} p<0.01$ versus timematched vehicle control. ${ }^{\#} p<0.05$ and ${ }^{\# \#} p<0.01$ versus URB $(50 \mu \mathrm{g})$.

60-g-evoked responses in sham-operated rats. The highest dose of URB597 studied significantly $(p<0.05)$ inhibited 15 - to 60 g-evoked responses in both sham-operated and SNL rats, compared with time-matched vehicle controls.

The contribution of spinal $\mathrm{CB}_{1}$ receptors to the effects of spinal URB597 was investigated in sham-operated and SNL rats. Spinal preadministration of the $\mathrm{CB}_{1}$ receptor antagonist AM251 $(1 \mu \mathrm{g}$ in $50 \mu \mathrm{l})$ alone had no significant effect on 10-, 15-, and 60 -g-evoked responses of WDR neurons in sham-operated or SNL rats. AM251 did, however, significantly increase 8- and 26g-evoked responses of WDR neurons in SNL rats compared with time-matched vehicle controls ( $8 \mathrm{~g}, p=0.02 ; 26 \mathrm{~g}, p=0.02$; Mann-Whitney test; $n=5)$. Spinal preadministration of AM251 $(1 \mu \mathrm{g}$ in $50 \mu \mathrm{l}$ ) significantly attenuated the effects of URB597 (50 $\mu \mathrm{g}$ in $50 \mu \mathrm{l}$ ) on 15- to 60 -g-evoked responses in sham-operated 


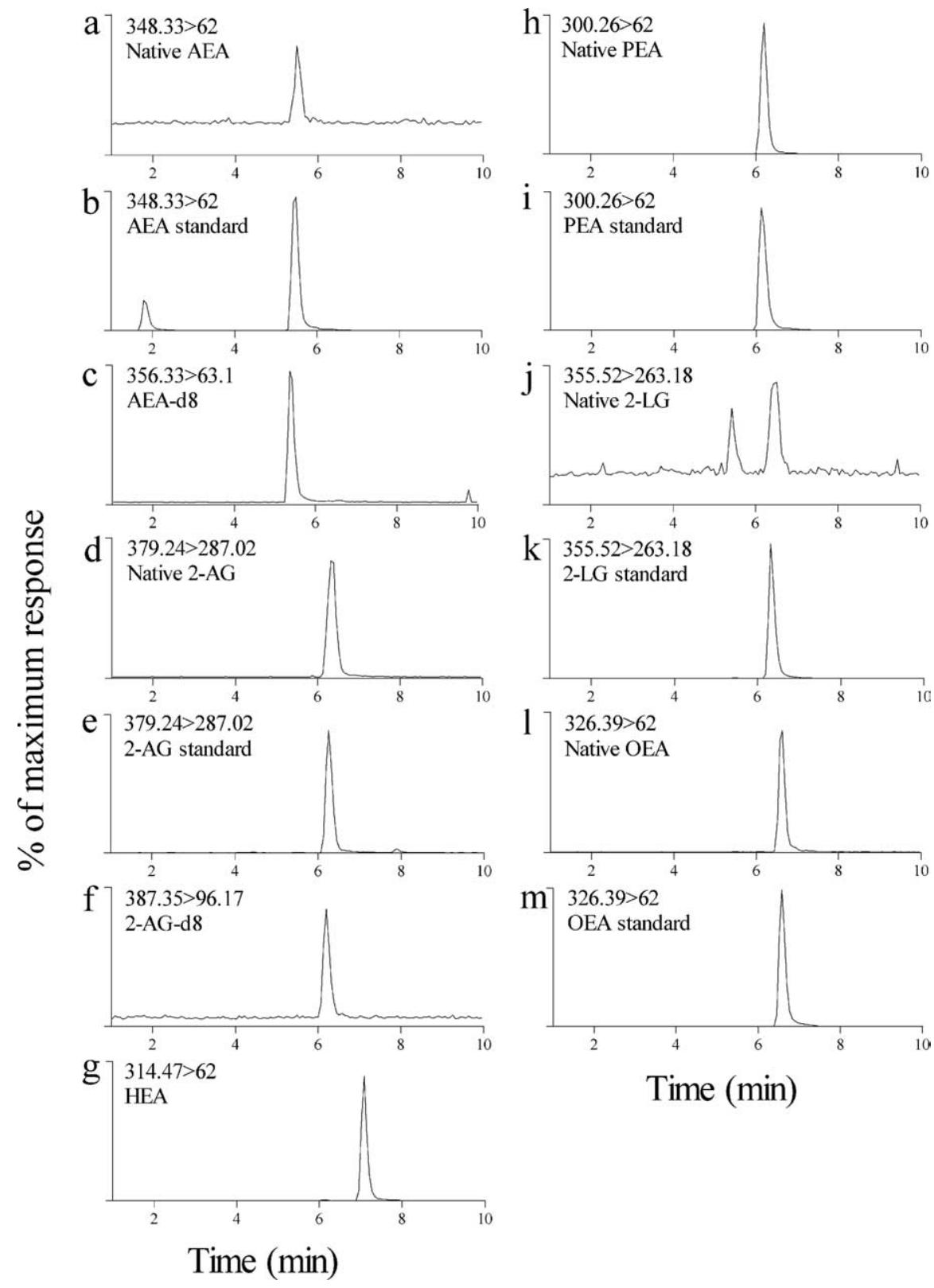

Figure 4. $\boldsymbol{a}-\boldsymbol{m}$, Representative chromatograms of native endocannabinoids and related fatty acids detected in rat paw tissue $(\boldsymbol{a}, \boldsymbol{d}, \boldsymbol{h}, \boldsymbol{j}, \boldsymbol{I})$, along with the corresponding synthetic standards used to construct calibration curves $(\boldsymbol{b}, \boldsymbol{e}, \boldsymbol{i}, \boldsymbol{k}, \boldsymbol{m})$ and the three internal standards, AEA-d8, 2AG-d8, and HEA (note differences in $m / z$ values) used to quantify levels of these compounds $(\boldsymbol{c}, \boldsymbol{f}, \boldsymbol{g})$. The additional peak in $\boldsymbol{b}$ corresponds with the virodhamine standard, which shares the precursor and product $m / z$ values with AEA and is therefore solely differentiated by chromatographic separation.

rats and 26- to 60-g-evoked responses in SNL rats (Fig. 3; for clarity of presentation, $15 \mathrm{~g}$ data are not presented).

The role of spinal opioid receptors in mediating the effects of spinally administered URB597 (50 $\mu \mathrm{g}$ in $15 \mu \mathrm{l}$ ) was also investigated. Preadministration of spinal naloxone $(15 \mu \mathrm{g}$ in $50 \mu \mathrm{l})$ attenuated the inhibitory effects of URB597 in both shamoperated and SNL rats to a similar extent. Naloxone significantly (mean \pm SEM; percentage of control: $15 \mathrm{~g}, 85 \pm 15 ; 26 \mathrm{~g}, 79 \pm 11$; $60 \mathrm{~g}, 92 \pm 9 ; p<0.05$; Mann-Whitney test; $n=5-6$ ) blocked the effects of URB597 (15 g, $36 \pm 10 ; 26 \mathrm{~g}, 37 \pm 10 ; 60 \mathrm{~g}, 29 \pm 6$ ) on mechanically evoked responses of dorsal horn neurons in shamoperated rats. Naloxone also significantly ( $p<0.05$; MannWhitney test; $n=6$ ) blocked the effects of URB597 in SNL rats (mean \pm SEM; percentage of control, naloxone plus URB597:
$15 \mathrm{~g}, 91 \pm 11 ; 26 \mathrm{~g}, 97 \pm 11 ; 60 \mathrm{~g}, 88 \pm 14$ vs URB597 alone: $15 \mathrm{~g}, 14 \pm 5 ; 26 \mathrm{~g}, 27 \pm$ 6 ; 60 g, $34 \pm 6$ ). Naloxone alone did not alter mechanically evoked responses of spinal neurons, compared with timematched vehicle controls (data not shown).

\section{Effects of intraplantar injection of} URB597 on levels of endocannabinoids In separate experiments, the effects of intraplantar injection of URB597 (25 $\mu \mathrm{g}$ in $50 \mu \mathrm{l}$ ), versus vehicle, on levels of endocannabinoids in the hindpaw were measured in sham-operated and SNL rats and compared with corresponding synthetic standards (Fig. 4). In sham-operated rats, intraplantar injection of vehicle had no significant effects on the levels of AEA, OEA, 2AG, or PEA in the ipsilateral hindpaw, compared with the contralateral paw (Fig. 5). Comparison of the effects of intraplantar injection of vehicle in SNL rats on levels of endocannabinoids and related fatty acids in the ipsilateral hindpaw revealed that injection of vehicle increased levels of AEA $(p<0.05)$ and OEA (not significant), compared with the contralateral paw of SNL rats (Fig. 5). Levels of AEA and OEA in the ipsilateral paw of vehicletreated SNL rats were also higher than in the vehicle-treated hindpaw of shamoperated rats. In contrast, intraplantar injection of vehicle did not significantly alter levels of 2AG in the ipsilateral hindpaw of SNL or sham-operated rats. Effects of vehicle treatment on levels of PEA and 2LG were more complex and did not follow a similar profile.

Twenty minutes after intraplantar injection of URB597 $(25 \mu \mathrm{g}$ in $50 \mu \mathrm{l})$ in sham-operated rats, levels of AEA, 2AG, and OEA were significantly increased in the ipsilateral hindpaw, compared with the contralateral hindpaw (Fig. 5). Increases in the levels of $2 \mathrm{AG}$ and OEA in the URB597-treated ipsilateral hindpaw of sham-operated rats were statistically significant compared with the effects of vehicle (Fig. 5). Thus, on the basis of the changes in levels of endocannabinoids and related fatty acids after intraplantar injection of URB597, we can conclude that the lower dose of URB597 produces inhibitory effects on neuronal responses in parallel with increased levels of endocannabinoids and related fatty acids in sham-operated rats. In contrast to sham-operated rats, intraplantar injection of URB597 $(25 \mu \mathrm{g}$ in $50 \mu \mathrm{l})$ did not alter levels of AEA, 2AG, OEA, PEA, and 2LG in the ipsilateral hindpaw of SNL rats, compared with contralateral hindpaw. Because in the electrophysiological studies a higher dose of URB597 (100 $\mu \mathrm{g}$ in 50 $\mu \mathrm{l}$ ) attenuated mechanically evoked responses of dorsal horn neurons in SNL rats, the ability of this dose of URB597 to modulate levels of endocannabinoids and related fatty acids in the hindpaw was also investigated. Intraplantar injection of a higher 
dose of URB597 (100 $\mu \mathrm{g}$ in $50 \mu \mathrm{l})$ in SNL rats decreased levels of AEA, 2AG, OEA, and PEA in the ipsilateral hindpaw, compared with the contralateral hindpaw; significance was only reached for OEA and PEA (Fig. 5). Both the low and high dose of URB597 decreased levels of AEA and OEA in the ipsilateral hindpaw compared with vehicle treatment in SNL rats. It is important to note, however, that levels of AEA and OEA were significantly higher in the ipsilateral hindpaw of vehicle-treated SNL rats compared with vehicle-treated shamoperated rats. These data indicate that there is a greater sensitivity of shamoperated rats to the effects of URB597 and that in SNL rats, endocannabinoids and related fatty acids are not elevated by URB597, suggesting that they are metabolized by alternative pathways.

\section{Effects of spinal administration of} URB597 on levels of endocannabinoids The effects of spinal administration of URB597 ( $50 \mu \mathrm{g}$ in $50 \mu \mathrm{l}$ ) versus vehicle on levels of endocannabinoids and related fatty acids was investigated in SNL and sham-operated rats. URB597 significantly $(p<0.05)$ increased levels of AEA and $2 \mathrm{AG}$ in the ipsilateral spinal cord of SNL rats, compared with vehicle treatment in SNL rats (Fig. 6). In contrast, URB597 did not alter levels of AEA in the ipsilateral or contralateral spinal cord of sham-operated rats compared with vehicle treatment (Fig. 5). URB597 did, however, significantly $(p<0.05)$ increase levels of $2 \mathrm{AG}$ in the ipsilateral and contralateral spinal cord of sham-operated rats compared with vehicle treatment (Fig. 6). URB597 significantly $(p<0.05)$ increased the levels of PEA in the ipsilateral spinal cord, compared with vehicle treatment in SNL rats, but had no significant effect on levels of PEA in shamoperated rats (data not shown). Spinal levels of OEA and 2LG were not altered by spinal administration of URB597 in SNL or sham-operated rats (data not shown).

\section{Discussion}

Intraplantar injection of URB597 elevated levels of AEA, OEA, and 2AG in the ipsilateral hindpaw and significantly reduced mechanically evoked responses of dorsal horn neurons in sham-operated rats. Inhibitory effects were attenuated by AM251, suggesting that elevated levels of $\mathrm{AEA}$ and $2 \mathrm{AG}$ act via $\mathrm{CB}_{1}$ receptors to produce their functional effects. In contrast, in neuropathic rats, the same intraplantar dose of URB597 had no effect, although a higher dose attenuated responses of spinal neurons in neuropathic rats, without increasing levels of endocannabinoids in the ipsilateral hindpaw.
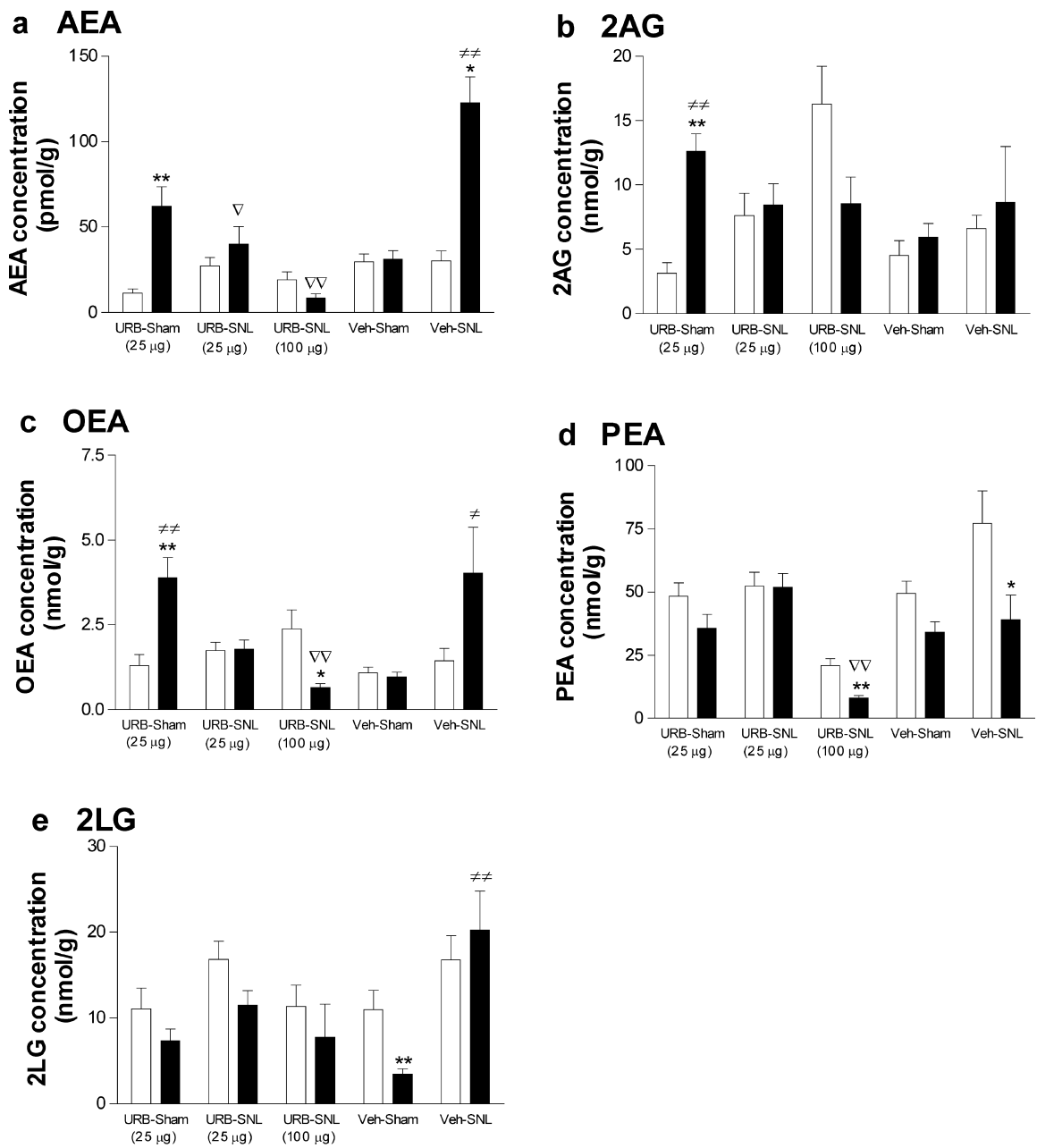

Figure 5. $\boldsymbol{a}-\boldsymbol{e}$, Effects of intraplantar injection of URB597 (URB; 25 or $100 \mu \mathrm{g}$ in $50 \mu \mathrm{l}$ ) on the levels of endocannabinoids ( $\boldsymbol{a}$, $\boldsymbol{c}$ ) and related fatty acids $(\boldsymbol{b}, \boldsymbol{d}, \boldsymbol{e})$ in the ipsilateral (filled bars) and contralateral (open bars) hindpaw of sham-operated and SNL rats. Data were analyzed using a Mann-Whitney nonparametric test and are expressed as mean + SEM picomoles per gram $(\boldsymbol{a})$ or nanomoles per gram $(\boldsymbol{b}-\boldsymbol{e})\left(n=6\right.$ rats per group). ${ }^{*} p<0.05$ and ${ }^{* *} p<0.01$ versus contralateral paw; ${ }^{*} p<0.05$ and ${ }^{\neq}{ }_{p}<0.01$ versus ipsilateral vehicle (Veh)-sham; $\nabla_{p}<0.05$ and $\nabla_{p}<0.01$ versus ipsilateral vehicle-SNL.
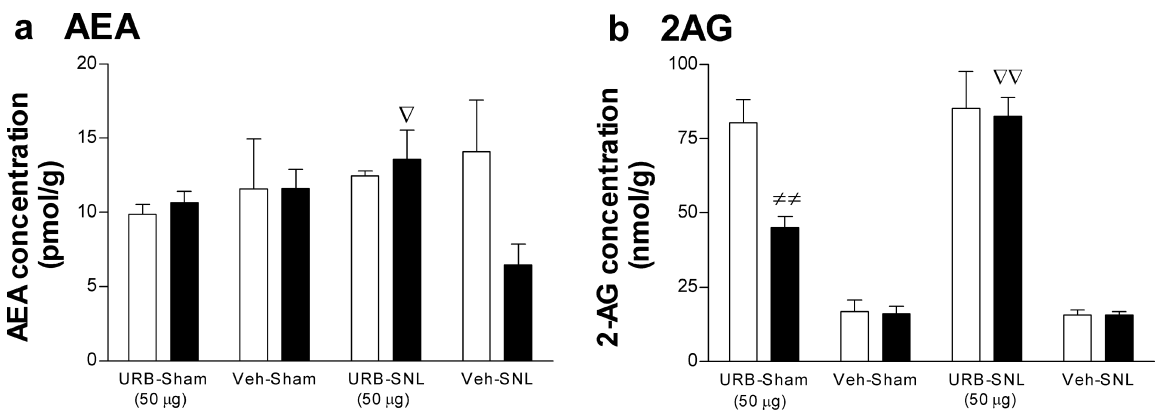

Figure 6. Effects of spinal administration of URB597 (URB; $50 \mu \mathrm{g}$ in $50 \mu \mathrm{l}$ ) on the levels of endocannabinoids in the ipsilateral (filled bars) and contralateral (open bars) spinal cord of sham-operated and SNL rats. $\boldsymbol{a}, \boldsymbol{b}$, Data were analyzed using a MannWhitney nonparametric test and are expressed as mean + SEM picomoles per gram (a) or nanomoles per gram $(\boldsymbol{b})(n=4-6$ rats per group). ${ }^{\neq \neq} p<0.01$ versus ipsilateral vehicle (Veh)-sham; $\nabla_{p}<0.05$ and $\nabla_{p}<0.01$ versus ipsilateral vehicle-SNL.

Metabolism of endocannabinoids and related fatty acid amides plays a major role in limiting their biological effects. Although FAAH is the predominant enzyme responsible for the metabolism of AEA, OEA, and PEA in the brain (Fegley et al., 2005), the contribution of different metabolic pathways (Mulder and Cravatt, 2006) in peripheral tissue or under conditions of 
pathology is unclear. Increased FAAH activity or changes in $\mathrm{pH}$ (Paylor et al., 2006) in the hindpaw of neuropathic rats could account for the reduced potency of URB597. Alternative routes of endocannabinoid metabolism, such as cyclooxygenase-2 (COX-2) (Kozak et al., 2004), may also be engaged in peripheral tissue in neuropathic pain states and contribute to endocannabinoid metabolism in the presence of FAAH inhibition. Indeed, increased COX-2 metabolism of AEA has been reported in FAAH-null mice (Weber et al., 2004). The inhibitory effects of the higher dose of URB597 in neuropathic rats were sensitive to a $\mathrm{CB}_{1}$ receptor antagonist but were not associated with elevated levels of AEA or $2 \mathrm{AG}$, indicating that, in the presence of FAAH inhibition, endocannabinoids are metabolized by alternative pathways to metabolites that modulate nociceptive processing or nonselective effects of this dose of URB597.

The peripheral effects of URB597 in sham-operated rats were mirrored by inhibitory effects of spinal URB597 in shamoperated rats, corroborating previous reports that FAAH inhibitors are antinociceptive in models of acute and inflammatory pain (Cravatt et al., 2001; Kathuria et al., 2003; Lichtman et al., 2004a,b; Holt et al., 2005; Jayamanne et al., 2006). Intrathecal URB597 increased levels of 2AG, but not AEA or PEA, in the ipsilateral spinal cord of sham-operated rats. Spinal administration of URB597 attenuated evoked responses of neurons in neuropathic rats and significantly increased levels of AEA, PEA, and 2AG in the ipsilateral spinal cord. Previously, it has been shown that a single dose of systemic URB597 does not alter neuropathic pain behavior (Jayamanne et al., 2006), whereas the FAAH inhibitor OL135 attenuated allodynia in neuropathic rats (Chang et al., 2006). Our data suggest that there may be tissue-specific changes in the sensitivity to URB597 in neuropathic rats, which may arise as a result of changes in FAAH activity, metabolic pathways, and tissue pH (Paylor et al., 2006).

Inhibitory effects of peripheral and spinal URB597 in SNL and sham-operated rats were blocked by AM251, demonstrating the contribution of $\mathrm{CB}_{1}$ receptors. $\mathrm{CB}_{1}$ receptor-mediated antinociception has been widely described in neuropathic rats (Herzberg et al., 1997; Mao et al., 2000; Bridges et al., 2001; Fox et al., 2001; Monhemius et al., 2001; Helyes et al., 2003; Lim et al., 2003; Scott et al., 2004; Pascual et al., 2005; Sagar et al., 2005). Our data are consistent with reports that $\mathrm{CB}_{1}$ receptors mediate the inhibitory effects of FAAH inhibitors (Cravatt et al., 2001; Kathuria et al., 2003; Lichtman et al., 2004a,b; Wilson et al., 2004; Hohmann et al., 2005; Jayamanne et al., 2006). URB597 has been shown to produce a rapid and sustained $(>6 \mathrm{~h})$ inhibition of FAAH activity in the brain and to increase levels of AEA and other related fatty acids (Kathuria et al., 2003; Fegley et al., 2005; Hohmann et al., 2005; Makara et al., 2005). URB597 does not bind to $\mathrm{CB}_{1}$ or $\mathrm{CB}_{2}$ receptors (Kathuria et al., 2003), suggesting that the effects of URB597 on evoked responses of spinal neurons arise as a result of $\mathrm{CB}_{1}$ receptor activation by the increased levels of AEA and $2 \mathrm{AG}$ in the ipsilateral hindpaw and spinal cord reported herein.

Inhibitory effects of peripherally and spinally administered URB597 in sham-operated rats were attenuated by the opioid antagonist naloxone, supporting evidence for interactions between the endocannabinoid and opioid receptor systems (Maldonado and Valverde, 2003; Ibrahim et al., 2005). In SNL rats, the inhibitory effects of the higher dose of intraplantar URB597 were not altered by naloxone. Inhibitory effects of spinal URB597, however, were significantly attenuated by naloxone in SNL rats. It has been reported recently that inhibitory effects of OL135 are also blocked by naloxone in SNL rats (Chang et al., 2006). Thus, it appears that opioid receptors contribute to cannabinoid- mediated analgesia in neuropathic pain states in a tissue-specific manner.

A major benefit of our analytical approach is the simultaneous measurement of endocannabinoids and related fatty acids. In sham-operated rats, inhibitory effects of intraplantar URB597 on nociceptive responses occurred in parallel with increased hindpaw levels of AEA, 2AG, and OEA. In contrast, levels of PEA and 2LG were not altered by intraplantar administration of URB597. FAAH is the main enzyme responsible for the metabolism of PEA in the brain. Previously, levels of PEA were shown to be increased in the duodenum of FAAH knock-out mice, but URB597 did not alter PEA levels in wild-type or FAAH knock-out mice, suggesting that additional pathways metabolize PEA in the periphery (Fegley et al., 2005). Indeed, an acid amidase enzyme is reported to be also responsible for the metabolism of PEA in peripheral tissue and macrophages (Ueda et al., 1999, 2001; Tsuboi et al., 2004; Sun et al., 2005). PEA is the preferred substrate for $\mathrm{N}$-acylethanolamine-hydrolyzing acid amidase, which is insensitive to URB597 (Sun et al., 2005). The lack of effect of URB597 on levels of PEA in hindpaw suggests that $\mathrm{N}$-acylethanolaminehydrolyzing acid amidase may play a role in the metabolism of PEA in the hindpaw, as has been described for other peripheral tissue.

Another important observation of the present study was that levels of $2 \mathrm{AG}$ in the hindpaw and spinal cord were elevated by URB597. 2AG has been shown to be metabolized by monoacylglycerol (MAG) lipase (Goparaju et al., 1999; Dinh et al., 2002; Saario et al., 2004) and FAAH in cell preparations (Cravatt et al., 1996; Bisogno et al., 1997; Goparaju et al., 1998, 1999; Ueda et al., 1998, 2002; Lang et al., 1999; Fowler et al., 2001). Our data using local administration of URB597 in vivo are in agreement with in vivo studies demonstrating that intraperiaqueductal gray injection of URB597 increases levels of AEA and 2AG (Maione et al., 2006) and that intraperitoneal injection of the FAAH inhibitor $\mathrm{N}$-arachidonyl-serotonin increases levels of $2 \mathrm{AG}$ in the brain (de Lago et al., 2005). In contrast, systemic administration of URB597 does not increase levels of 2AG (Kathuria et al., 2003; Fegley et al., 2005), and levels of 2AG are not altered in FAAH knock-out mice (Fegley et al., 2005). Because URB597 is reported to have no inhibitory effects on MAG lipase (Kathuria et al., 2003; Lichtman et al., 2004b; Hohmann et al., 2005; Makara et al., 2005), the present results suggest that $2 \mathrm{AG}$ may be metabolized by FAAH in vivo. Alternatively, the increases in $2 \mathrm{AG}$ after administration of URB597 may arise because of indirect circuit effects of FAAH inhibition on the production and metabolism of $2 \mathrm{AG}$.

An important consideration when using FAAH inhibitors is that some endocannabinoids, such as AEA, are also agonists (Zygmunt et al., 1999; Smart and Jerman, 2000; Smart et al., 2000) at pronociceptive transient receptor potential vanilloid subfamily member 1 (TRPV1) receptors, which are upregulated in primary afferent fibers in neuropathic rats (Macdonald et al., 2001; Fukuoka et al., 2002; Rashid et al., 2003a,b). In the present study, levels of AEA and OEA, but not 2AG, were increased after injection of vehicle in the hindpaw of neuropathic but not shamoperated rats. The increased tissue content of endocannabinoid may reflect either increased synthesis or reduced metabolism in the neuropathic rats, but, given the attenuated response to URB597 in the neuropathic rats, the latter seems unlikely. The mechanism responsible for increased levels of AEA and OEA in response to vehicle injection in neuropathic rats is unknown, although one possibility is an upregulation of TRPV1 receptor, which has been suggested to act as an integrator and amplifier of 
calcium-mobilizing signals via intracellular AEA synthesis (van der Stelt et al., 2005).

In conclusion, peripheral and spinal administration of URB597 increased levels of AEA, 2AG, and OEA in the hindpaw and reduced nociceptive processing in sham-operated rats in a $\mathrm{CB}_{1}$ receptor-dependent manner. The requirement for a higher intraplantar dose of URB597 in neuropathic rats to attenuate nociceptive responses suggests that the contribution of FAAH to endocannabinoid metabolism is altered in neuropathy. These changes do not appear to be global, because spinal inhibition of FAAH was equally effective in sham-operated and neuropathic rats and was associated with increased levels of AEA, PEA, and 2AG.

\section{References}

Bisogno T, Sepe N, Melck D, Maurelli S, De Petrocellis L, Di Marzo V (1997) Biosynthesis, release and degradation of the novel endogenous cannabimimetic metabolite 2-arachidonoylglycerol in mouse neuroblastoma cells. Biochem J 322:671-677.

Bridges D, Ahmad K, Rice AS (2001) The synthetic cannabinoid WIN55,212-2 attenuates hyperalgesia and allodynia in a rat model of neuropathic pain. Br J Pharmacol 133:586-594.

Calignano A, La Rana G, Giuffrida A, Piomelli D (1998) Control of pain initiation by endogenous cannabinoids. Nature 394:277-281.

Chang L, Luo L, Palmer JA, Sutton S, Wilson SJ, Barbier AJ, Breitenbucher JG, Chaplan SR, Webb M (2006) Inhibition of fatty acid amide hydrolase produces analgesia by multiple mechanisms. $\mathrm{Br} \mathrm{J}$ Pharmacol 148:102-113.

Chaplan SR, Bach FW, Pogrel JW, Chung JM, Yaksh TL (1994) Quantitative assessment of tactile allodynia in the rat paw. J Neurosci Methods 53:55-63.

Chapman V (1999) The cannabinoid CB1 receptor antagonist, SR141716A, selectively facilitates nociceptive responses of dorsal horn neurones in the rat. Br J Pharmacol 127:1765-1767.

Chapman V, Suzuki R, Dickenson AH (1998) Electrophysiological characterization of spinal neuronal response properties in anaesthetized rats after ligation of spinal nerves L5-L6. J Physiol (Lond) 507:881-894.

Clement AB, Hawkins EG, Lichtman AH, Cravatt BF (2003) Increased seizure susceptibility and proconvulsant activity of anandamide in mice lacking fatty acid amide hydrolase. J Neurosci 23:3916-3923.

Cravatt BF, Giang DK, Mayfield SP, Boger DL, Lerner RA, Gilula NB (1996) Molecular characterization of an enzyme that degrades neuromodulatory fatty-acid amides. Nature 384:83-87.

Cravatt BF, Demarest K, Patricelli MP, Bracey MH, Giang DK, Martin BR, Lichtman AH (2001) Supersensitivity to anandamide and enhanced endogenous cannabinoid signaling in mice lacking fatty acid amide hydrolase. Proc Natl Acad Sci USA 98:9371-9376.

de Lago E, Petrosino S, Valenti M, Morera E, Ortega-Gutierrez S, FernandezRuiz J, Di Marzo V (2005) Effect of repeated systemic administration of selective inhibitors of endocannabinoid inactivation on rat brain endocannabinoid levels. Biochem Pharmacol 70:446-452.

Desarnaud F, Cadas H, Piomelli D (1995) Anandamide amidohydrolase activity in rat brain microsomes. Identification and partial characterization. J Biol Chem 270:6030-6035.

Deutsch DG, Chin SA (1993) Enzymatic synthesis and degradation of anandamide, a cannabinoid receptor agonist. Biochem Pharmacol 46:791-796.

Dickenson AH, Sullivan AF (1986) Electrophysiological studies on the effects of intrathecal morphine on nociceptive neurones in the rat dorsal horn. Pain 24:211-222.

Dinh TP, Carpenter D, Leslie FM, Freund TF, Katona I, Sensi SL, Kathuria S, Piomelli D (2002) Brain monoglyceride lipase participating in endocannabinoid inactivation. Proc Natl Acad Sci USA 99:10819-10824.

Dogrul A, Gardell LR, Ma S, Ossipov MH, Porreca F, Lai J (2002) 'Knockdown' of spinal CB1 receptors produces abnormal pain and elevates spinal dynorphin content in mice. Pain 100:203-209.

Elmes SJ, Jhaveri MD, Smart D, Kendall DA, Chapman V (2004) Cannabinoid $\mathrm{CB} 2$ receptor activation inhibits mechanically evoked responses of wide dynamic range dorsal horn neurons in naive rats and in rat models of inflammatory and neuropathic pain. Eur J Neurosci 20:2311-2320.
Fegley D, Gaetani S, Duranti A, Tontini A, Mor M, Tarzia G, Piomelli D (2005) Characterization of the fatty acid amide hydrolase inhibitor cyclohexyl carbamic acid 3'-carbamoyl-biphenyl-3-yl ester (URB597): effects on anandamide and oleoylethanolamide deactivation. J Pharmacol Exp Ther 313:352-358.

Fowler CJ, Jonsson KO, Tiger G (2001) Fatty acid amide hydrolase: biochemistry, pharmacology, and therapeutic possibilities for an enzyme hydrolyzing anandamide, 2-arachidonoylglycerol, palmitoylethanolamide, and oleamide. Biochem Pharmacol 62:517-526.

Fox A, Kesingland A, Gentry C, McNair K, Patel S, Urban L, James I (2001) The role of central and peripheral Cannabinoid1 receptors in the antihyperalgesic activity of cannabinoids in a model of neuropathic pain. Pain 92:91-100.

Fukuoka T, Tokunaga A, Tachibana T, Dai Y, Yamanaka H, Noguchi K (2002) VR1, but not P2X3, increases in the spared L4 DRG in rats with L5 spinal nerve ligation. Pain 99:111-120.

Goparaju SK, Ueda N, Yamaguchi H, Yamamoto S (1998) Anandamide amidohydrolase reacting with 2-arachidonoylglycerol, another cannabinoid receptor ligand. FEBS Lett 422:69-73.

Goparaju SK, Ueda N, Taniguchi K, Yamamoto S (1999) Enzymes of porcine brain hydrolyzing 2-arachidonoylglycerol, an endogenous ligand of cannabinoid receptors. Biochem Pharmacol 57:417-423.

Helyes Z, Nemeth J, Than M, Bolcskei K, Pinter E, Szolcsanyi J (2003) Inhibitory effect of anandamide on resiniferatoxin-induced sensory neuropeptide release in vivo and neuropathic hyperalgesia in the rat. Life Sci 73:2345-2353.

Herzberg U, Eliav E, Bennett GJ, Kopin IJ (1997) The analgesic effects of $\mathrm{R}(+$ )-WIN 55,212-2 mesylate, a high affinity cannabinoid agonist, in a rat model of neuropathic pain. Neurosci Lett 221:157-160.

Hohmann AG (2002) Spinal and peripheral mechanisms of cannabinoid antinociception: behavioral, neurophysiological and neuroanatomical perspectives. Chem Phys Lipids 121:173-190.

Hohmann AG, Suplita RL, Bolton NM, Neely MH, Fegley D, Mangieri R, Krey JF, Walker JM, Holmes PV, Crystal JD, Duranti A, Tontini A, Mor M, Tarzia G, Piomelli D (2005) An endocannabinoid mechanism for stress-induced analgesia. Nature 435:1108-1112.

Holt S, Comelli F, Costa B, Fowler CJ (2005) Inhibitors of fatty acid amide hydrolase reduce carrageenan-induced hind paw inflammation in pentobarbital-treated mice: comparison with indomethacin and possible involvement of cannabinoid receptors. Br J Pharmacol 146:467-476.

Howlett AC, Barth F, Bonner TI, Cabral G, Casellas P, Devane WA, Felder CC, Herkenham M, Mackie K, Martin BR, Mechoulam R, Pertwee RG (2002) International Union of Pharmacology. XXVII. Classification of cannabinoid receptors. Pharmacol Rev 54:161-202.

Ibrahim MM, Porreca F, Lai J, Albrecht PJ, Rice FL, Khodorova A, Davar G, Makriyannis A, Vanderah TW, Mata HP, Malan Jr TP (2005) CB2 cannabinoid receptor activation produces antinociception by stimulating peripheral release of endogenous opioids. Proc Natl Acad Sci USA 102:3093-3098.

Jayamanne A, Greenwood R, Mitchell VA, Aslan S, Piomelli D, Vaughan CW (2006) Actions of the FAAH inhibitor URB597 in neuropathic and inflammatory chronic pain models. Br J Pharmacol 147:281-288.

Jhaveri MD, Elmes SJ, Kendall DA, Chapman V (2005) Inhibition of peripheral vanilloid TRPV1 receptors reduces noxious heat-evoked responses of dorsal horn neurons in naive, carrageenan-inflamed and neuropathic rats. Eur J Neurosci 22:361-370.

Johanek LM, Simone DA (2004) Activation of peripheral cannabinoid receptors attenuates cutaneous hyperalgesia produced by a heat injury. Pain 109:432-442.

Kathuria S, Gaetani S, Fegley D, Valino F, Duranti A, Tontini A, Mor M, Tarzia G, La Rana G, Calignano A, Giustino A, Tattoli M, Palmery M, Cuomo V, Piomelli D (2003) Modulation of anxiety through blockade of anandamide hydrolysis. Nat Med 9:76-81.

Kim SH, Chung JM (1992) An experimental model for peripheral neuropathy produced by segmental spinal nerve ligation in the rat. Pain 50:355-363.

Kozak KR, Prusakiewicz JJ, Marnett LJ (2004) Oxidative metabolism of endocannabinoids by COX-2. Curr Pharm Des 10:659-667.

Lang W, Qin C, Lin S, Khanolkar AD, Goutopoulos A, Fan P, Abouzid K, Meng Z, Biegel D, Makriyannis A (1999) Substrate specificity and stereoselectivity of rat brain microsomal anandamide amidohydrolase. J Med Chem 42:896-902. 
Lichtman AH, Shelton CC, Advani T, Cravatt BF (2004a) Mice lacking fatty acid amide hydrolase exhibit a cannabinoid receptor-mediated phenotypic hypoalgesia. Pain 109:319-327.

Lichtman AH, Leung D, Shelton CC, Saghatelian A, Hardouin C, Boger DL, Cravatt BF (2004b) Reversible inhibitors of fatty acid amide hydrolase that promote analgesia: evidence for an unprecedented combination of potency and selectivity. J Pharmacol Exp Ther 311:441-448.

Lim G, Sung B, Ji R-R, Mao J (2003) Upregulation of spinal cannabinoid-1receptors following nerve injury enhances the effects of Win 55,212-2 on neuropathic pain behaviors in rats. Pain 105:275-283.

Macdonald R, Bingham S, Bond BC, Parsons AA, Philpott KL (2001) Determination of changes in mRNA expression in a rat model of neuropathic pain by Taqman quantitative RT-PCR. Brain Res Mol Brain Res 90:48-56.

Maione S, Bisogno T, de Novellis V, Palazzo E, Cristino L, Valenti M, Petrosino S, Guglielmotti V, Rossi F, Marzo VD (2006) Elevation of endocannabinoid levels in the ventrolateral periaqueductal grey through inhibition of fatty acid amide hydrolase affects descending nociceptive pathways via both cannabinoid receptor type 1 and transient receptor potential vanilloid type-1 receptors. J Pharmacol Exp Ther 316:969-982.

Makara JK, Mor M, Fegley D, Szabo SI, Kathuria S, Astarita G, Duranti A, Tontini A, Tarzia G, Rivara S, Freund TF, Piomelli D (2005) Selective inhibition of 2-AG hydrolysis enhances endocannabinoid signaling in hippocampus. Nat Neurosci 8:1139-1141.

Maldonado R, Valverde O (2003) Participation of the opioid system in cannabinoid-induced antinociception and emotional-like responses. Eur Neuropsychopharmacol 13:401-410.

Mao J, Price DD, Lu J, Keniston L, Mayer DJ (2000) Two distinctive antinociceptive systems in rats with pathological pain. Neurosci Lett 280:13-16.

Maurelli S, Bisogno T, De Petrocellis L, Di Luccia A, Marino G, Di Marzo V (1995) Two novel classes of neuroactive fatty acid amides are substrates for mouse neuroblastoma "anandamide amidohydrolase." FEBS Lett 377:82-86.

Monhemius R, Azami J, Green DL, Roberts MH (2001) CB1 receptor mediated analgesia from the Nucleus Reticularis Gigantocellularis pars alpha is activated in an animal model of neuropathic pain. Brain Res 908:67-74.

Mulder AM, Cravatt BF (2006) Endocannabinoid metabolism in the absence of fatty acid amide hydrolase (FAAH): discovery of phosphorylcholine derivatives of $\mathrm{N}$-acyl ethanolamines. Biochemistry 45:11267-11277.

Pascual D, Goicoechea C, Suardiaz M, Martin MI (2005) A cannabinoid agonist, WIN 55,212-2, reduces neuropathic nociception induced by paclitaxel in rats. Pain 118:23-34.

Paylor B, Holt S, Fowler CJ (2006) The potency of the fatty acid amide hydrolase inhibitor URB597 is dependent upon the assay pH. Pharmacol Res 54:481-485.

Rashid MH, Inoue M, Kondo S, Kawashima T, Bakoshi S, Ueda H (2003a) Novel expression of vanilloid receptor 1 on capsaicin-insensitive fibers accounts for the analgesic effect of capsaicin cream in neuropathic pain. J Pharmacol Exp Ther 304:940-948.

Rashid MH, Inoue M, Bakoshi S, Ueda H (2003b) Increased expression of vanilloid receptor 1 on myelinated primary afferent neurons contributes to the antihyperalgesic effect of capsaicin cream in diabetic neuropathic pain in mice. J Pharmacol Exp Ther 306:709-717.

Richardson D, Ortori CA, Chapman V, Kendall DA, Barrett DA (2006) Quantitative profiling of endocannabinoids and related compounds in rat brain using liquid chromatography-tandem electrospray ionisation mass spectrometry. Anal Biochem, in press.

Richardson JD, Aanonsen L, Hargreaves KM (1997) SR 141716A, a cannabinoid receptor antagonist, produces hyperalgesia in untreated mice. Eur J Pharmacol 319:R3-R4.

Richardson JD, Aanonsen L, Hargreaves KM (1998) Hypoactivity of the spinal cannabinoid system results in NMDA-dependent hyperalgesia. J Neurosci 18:451-457.
Saario SM, Savinainen JR, Laitinen JT, Jarvinen T, Niemi R (2004) Monoglyceride lipase-like enzymatic activity is responsible for hydrolysis of 2 -arachidonoylglycerol in rat cerebellar membranes. Biochem Pharmacol 67:1381-1387.

Sagar DR, Kelly S, Millns PJ, O'Shaughnessey CT, Kendall DA, Chapman V (2005) Inhibitory effects of CB1 and CB2 receptor agonists on responses of DRG neurons and dorsal horn neurons in neuropathic rats. Eur J Neurosci 22:371-379.

Scott DA, Wright CE, Angus JA (2004) Evidence that CB-1 and CB-2 cannabinoid receptors mediate antinociception in neuropathic pain in the rat. Pain 109:124-131.

Smart D, Jerman JC (2000) Anandamide: an endogenous activator of the vanilloid receptor. Trends Pharmacol Sci 21:134.

Smart D, Gunthorpe MJ, Jerman JC, Nasir S, Gray J, Muir AI, Chambers JK, Randall AD, Davis JB (2000) The endogenous lipid anandamide is a full agonist at the human vanilloid receptor (hVR1). Br J Pharmacol 129:227-230.

Sokal DM, Chapman V (2001) Spinal GABA(B)-receptor antagonism increases nociceptive transmission in vivo. NeuroReport 12:3247-3250.

Strangman NM, Patrick SL, Hohmann AG, Tsou K, Walker JM (1998) Evidence for a role of endogenous cannabinoids in the modulation of acute and tonic pain sensitivity. Brain Res 813:323-328.

Sun YX, Tsuboi K, Zhao LY, Okamoto Y, Lambert DM, Ueda N (2005) Involvement of $\mathrm{N}$-acylethanolamine-hydrolyzing acid amidase in the degradation of anandamide and other $\mathrm{N}$-acylethanolamines in macrophages. Biochim Biophys Acta 1736:211-220.

Tsuboi K, Hilligsmann C, Vandevoorde S, Lambert DM, Ueda N (2004) $\mathrm{N}$-cyclohexanecarbonylpentadecylamine: a selective inhibitor of the acid amidase hydrolysing $\mathrm{N}$-acylethanolamines, as a tool to distinguish acid amidase from fatty acid amide hydrolase. Biochem J 379:99-106.

Ueda N (2002) Endocannabinoid hydrolases. Prostaglandins Other Lipid Mediat 68-69:521-534.

Ueda N, Kurahashi Y, Yamamoto S, Tokunaga T (1995) Partial purification and characterization of the porcine brain enzyme hydrolyzing and synthesizing anandamide. J Biol Chem 270:23823-23827.

Ueda N, Goparaju SK, Katayama K, Kurahashi Y, Suzuki H, Yamamoto S (1998) A hydrolase enzyme inactivating endogenous ligands for cannabinoid receptors. J Med Invest 45:27-36.

Ueda N, Yamanaka K, Terasawa Y, Yamamoto S (1999) An acid amidase hydrolyzing anandamide as an endogenous ligand for cannabinoid receptors. FEBS Lett 454:267-270.

Ueda N, Yamanaka K, Yamamoto S (2001) Purification and characterization of an acid amidase selective for $\mathrm{N}$-palmitoylethanolamine, a putative endogenous anti-inflammatory substance. J Biol Chem 276:35552-35557.

van der Stelt M, Trevisani M, Vellani V, De Petrocellis L, Schiano Moriello A, Campi B, McNaughton P, Geppetti P, Di Marzo V (2005) Anandamide acts as an intracellular messenger amplifying Ca2+ influx via TRPV1 channels. EMBO J 24:3026-3037.

Weber A, Ni J, Ling KH, Acheampong A, Tang-Liu DD, Burk R, Cravatt BF, Woodward D (2004) Formation of prostamides from anandamide in FAAH knockout mice analyzed by HPLC with tandem mass spectrometry. J Lipid Res 45:757-763.

Wilson AW, Clayton NM, Medhurst SJ, Bountra C, Chessel IP (2004) The FAAH inhibitor URB597 reverses inflammatory pain through a CB1 receptor mediated mechanism. Proceedings of the British Pharmacological Society. Retrieved November 21, 2006, from http://www.pA2online.org/ Vol2Issue4abst049P.html.

Zygmunt PM, Petersson J, Andersson DA, Chuang H, Sorgard M, Di Marzo V, Julius D, Hogestatt ED (1999) Vanilloid receptors on sensory nerves mediate the vasodilator action of anandamide. Nature 400:452-457. 